\title{
Buddyjska magia przed powstaniem wadźrajany
}

\author{
Marek Szymański
}

http://orcid.org/0000-0003-3233-2678

Pogląd, zgodnie z którym obrzędy magiczne są w obrębie buddyzmu elementem obcym, jest rażąco błędny, jeśli rozpatrywać go w perspektywie historycznej. Rozwój buddyjskiej magii sięga początków tej religii. Do praktyk magicznych powszechnie odwoływali się świeccy wyznawcy i mnisi reprezentujący indyjską śrawakajanę i mahajanę. Za rytuały magiczne można uznać szeroko rozpowszechnione praktyki buddyjskie, takie jak recytacja tekstów ochronnych, oddawanie czci Śakjamuniemu w miejscach szczególnie ważnych w jego życiu, kult stup, kult wizerunków buddów i bodhisattwów. Obrzędowym działaniom charakterystycznym dla praktyk magicznych przypisano nawet funkcję zbawczą, co świadczy o ich randze. Dążenie do rytualnego wpływania na przebieg zdarzeń osiągnęło kulminację w nurcie mahajany, który jest znany z tekstów zwanych „dharani-sutrami”. Dają one wyraz fascynacji magią jako narzędziem przekształcania otoczenia i samego siebie. Stanowią również świadectwo śmiałego czerpania z obcych tradycji liturgicznych. W wielu dharani-sutrach mamy do czynienia z przypisaniem rytuałom o proweniencji magicznej statusu głównego czynnika w procesie zbawczej transformacji umysłu. Wadźrajana rozwinęła się na gruncie podejścia znanego z dharani-sutr.

Słowa kluczowe: buddyzm, magia, dharani, dharani-sutry, magia

W wadźrajanie (nazywanej również „buddyzmem tantrycznym” lub „buddyzmem ezoterycznym”) ważną rolę odgrywają obrzędy magiczne. Wiele tantr,

MAREK SZYMAŃSKI, doktor habilitowany, Instytut Filozofii, Uniwersytet Marii Curie-Skłodowskiej; adres do korespondencji: Instytut Filozofii UMCS, Pl. Marii Curie-Skłodowskiej 4, 20-031 Lublin; e-mail: marek.szymanski@poczta.umcs.lublin.pl 
czyli podstawowych tekstów wadźrajany uznawanych za w pełni wiarygodne słowa buddy ( buddha-vacana ${ }^{2}$ ), jest poświęconych rytuałom właśnie tego rodzaju. Magia zajmuje ważne miejsce również w wielu z tych tantr, których autorzy uznawali nadrzędność perspektywy soteriologicznej. W grę wchodzi zarówno magia dobroczynna, jak i taka, która ma na celu wykorzystanie innych osób, wyrządzenie im takiej czy innej szkody, a nawet spowodowanie śmierci. Co więcej, działania charakterystyczne dla praktyk magicznych (m. in. recytowanie mantr, wykonywanie mudr, posługiwanie się mandalami i składanie ofiar) są uznawane przez autorów tantr za ważny składnik technik prowadzących do osiągnięcia stanu buddy. Po zakończeniu okresu formacyjnego obrzędy magiczne oraz odpowiadające im instrumenty zbawczej transformacji pozostały integralną częścią wadźrajany.

Taki stan rzeczy zaskakuje tych, którzy odwołują się do rozpowszechnionego w kulturze Zachodu zracjonalizowanego obrazu buddyzmu jako religii, która ogranicza się do rozwoju cnót moralnych i poznawczych. W rzeczywistości wszystkie znane postaci tradycyjnego buddyzmu indyjskiego (w artykule pomijam kwestię tzw. buddyzmu pierwotnego, którego rekonstrukcja pozostaje $\mathrm{w}$ wielu aspektach problematyczna) były bardziej złożone i obejmowały praktyki magiczne. W przypadku wadźrajany mamy do czynienia nie z przełomem polegającym na zwróceniu się do paradygmatu aktywności magicznej, ale z kontynuacją długiej buddyjskiej tradycji rytualnego oddziaływania na przebieg zdarzeń w świecie. Celem autora niniejszego tekstu jest przedstawienie dziejów buddyjskiej magii przed powstaniem buddyzmu tantrycznego ${ }^{3}$.

Badacze religii nie są zgodni co do sposobu rozumienia magii ${ }^{4}$. W niniejszym tekście magia jest rozumiana jako aktywność, której można przypisać następujące cechy:

1) rytualny charakter;

\footnotetext{
${ }^{2}$ Wszystkie terminy indyjskie podano w wersji sanskryckiej.

${ }^{3}$ Artykuł został pomyślany jako pierwszy z cyklu trzech tekstów. Kolejne będą poświęcone procesowi, który doprowadził do wyłonienia się wadźrajany z obrzędowości znanej z dharani-sutr i stworzonej pod wpływem fascynacji magią, oraz praktykom magicznym w tzw. tantrach najwyższej jogi. Chociaż niniejszy tekst ma w zasadzie charakter syntetyczny, to zawiera pewne propozycje natury analitycznej w zakresie interpretacji obszernego i różnorodnego materiału (chodzi m.in. o wykorzystane pojęcie buddyjskiej magii oraz o interpretację sposobu rozumienia przez buddystów rezultatu pewnych postaci aktywności - jako karmicznej zasługi i zarazem skutku ingerencji czynnika nadprzyrodzonego).

${ }^{4}$ Zob. np. John Middleton, „Magic: Theories of Magic”, w: Encyclopedia of Religion, red. Lindsay Jones, t. 8 (Detroit: Thomson Gale, 2005), 5562-5569.
} 
2) odwoływanie się do sił lub istot o charakterze religijnym jako czynników sprawczych;

3) posiadanie celu w postaci konkretnego zdarzenia lub mniej czy bardziej określonego stanu, które mają charakter doczesny, zaś ich wystąpienie jest oczekiwane w bieżącym albo (rzadziej) kolejnym cyklu życiowym (cel pragmatyczny, a nie soteriologiczny);

4) występowanie przekonania, że właściwie odprawiony rytuał prowadzi do pożądanego rezultatu (pomimo ewentualnego poczucia niepewności związanego z przeświadczeniem o kontakcie z siłami potężnymi i niepoddającymi się pełnej kontroli).

Tak zdefiniowaną magię można w obrębie buddyzmu przeciwstawić innym postaciom aktywności religijnej:

1) takim działaniom (niektóre $z$ nich są zrytualizowane) podejmowanym z uwagi na ich karmiczne owoce, w przypadku których związek między czynami a ich pożądanymi rezultatami jest rozumiany jako zależność przyczynowo-skutkowa o charakterze naturalnym (tj. zależność stała i niezależna od ekstraordynaryjnych czynników o charakterze religijnym, do których odwołują się obrzędy magiczne);

2) wszelkim działaniom (rytualnym oraz innym), które służą realizacji celu soteriologicznego;

3) działaniom o charakterystyce zbliżonej do aktywności magicznej (posiadającym jej cechy wskazane wyżej jako druga i trzecia), które mają charakter improwizowany, a nie rytualny.

Rozumiana w powyższy sposób buddyjska magia nie stanowi dokładnego odpowiednika buddyzmu apotropaicznego w rozumieniu Melforda Spiro. Spiro w swym klarownym podziale aktywności buddystów birmańskich wykorzystał jako kryterium odmienność celów (w buddyzmie nirwanicznym celem jest nirwana, w buddyzmie karmicznym - moralna zasługa i jej doczesne owoce w przyszłości, w buddyzmie apotropaicznym - doraźna ochrona lub pomyślność) oraz przyporządkowanych im środków (medytacja w buddyzmie karmicznym, przestrzeganie zasad moralnych $\mathrm{w}$ buddyzmie karmicznym oraz odwołanie się do czynników supranaturalnych $\mathrm{w}$ buddyzmie apotropaicznym) $)^{5}$. Owo ścisłe przyporządkowanie celów i środków wydaje się nadmiernym uproszczeniem.

${ }^{5}$ Melford E. Spiro, Buddhism and Society: A Great Tradition and Its Burmese Vicissitudes (Berkeley-Los Angeles: University of California Press, 1982), 11-13. 
Wykorzystywane w niniejszym tekście pojęcie buddyjskiej magii jest zakresowo szersze od kategorii buddyzmu apotropaicznego, gdyż obejmuje zarówno obrzędy ochronne lub zapewniające pomyślność w tym życiu (z uwzględnieniem tzw. czarnej magii), jak również liczne rytuały odprawiane, by wywrzeć określony wpływ na przebieg przyszłych cykli życiowych uczestnika obrzędu lub innych osób ${ }^{6}$. Autor jest świadom powiązań między wyżej wyróżnionymi kategoriami zachowań religijnych buddystów ( $w$ niektórych przypadkach w grę wchodzi strukturalna zależność) oraz istnienia obrzędów, których przyporządkowanie jednej tylko kategorii jest niemożliwe?

Zważywszy na brak zgody co do sposobu rozumienia słowa „magia” w religioznawstwie, projektujący charakter wyżej przedstawionej definicji nie powinien budzić zasadniczych zastrzeżeń. W kontekście badań nad buddyzmem wprowadzona kategoria magii pozwala wyodrębnić i poddać analizie klasę zachowań motywowanych religijnie, które są pokrewne strukturalnie i funkcjonalnie (pomimo odmienności pod wieloma względami). Zabieg ten pomaga ujawnić niezmiennie ważną rolę takiego składnika religii buddyjskiej, który jest często ignorowany lub lekceważony, i wykazać, tym samym, fałszywość rozpowszechnionych na Zachodzie przekonań na temat buddyzmu. Niektórzy badacze religii kwestionują kognitywną wartość pojęcia magii, widząc w nim rezultat dychotomicznego myślenia motywowanego ideologicznie ${ }^{8}$. Stosowana w niniejszym tekście kategoria magii nie ma charakteru wartościującego. Autor ma nadzieję, że można zignorować ryzyko wypaczenia recepcji niniejszego tekstu przez pejoratywne skojarzenia tradycyjnie wywoływane przez termin „magia”. Współczesna kultura popularna wręcz odwróciła wszak aksjologiczny wektor asocjacji związanych z rozpatrywanym słowem.

${ }^{6}$ Przyporządkowując środki celom, Spiro koncentrował się na współczesnej therawadzie i nie uwzględnił m.in. tego, że buddyści w dążeniu do stanu buddy wykorzystywali i wykorzystują różnorodne instrumenty (w tym rytuały, które mają wywołać aktywność czynników nadprzyrodzonych).

${ }^{7}$ Por. Rupert Gethin, The Foundations of Buddhism (Oxford: Oxford University Press, 1998), 110-111; Goeffrey Samuel, Civilized Shamans. Buddhism in Tibetan Societes (Washington-London: Smithsonian Institution Press, 1993), 24-29.

${ }^{8} \mathrm{~Np}$. Wouter J. Hanegraaff, Esotericism and the Academy: Rejected Knowledge in Western Culture (Cambridge: Cambridge University Press, 2012), 166-169. 


\section{Magia w śrawakajanie}

Przekonanie niektórych współczesnych apologetów lub badaczy buddyzmu (próbujących dokonać racjonalizacji tej religii), że buddyzm i magia są niemożliwe do pogodzenia, jest opinią, której błędność łatwo wykazać w perspektywie historycznej ${ }^{9}$. Buddyści zawsze wierzyli, że duchowy rozwój adepta zapewnia mu bezpieczeństwo oraz cudowną władzę nad światem. Przyjmowano również, że obecność Buddy w danym miejscu chroni przebywające tam osoby. $Z$ tym przekonaniem związany jest dominujący we wczesnym buddyzmie sposób przedstawiania Śakjamuniego z podniesioną dłonią z wyprostowanymi palcami, którym to gestem Budda zapewnia zwolenników o ich bezpieczeństwie (mudra abhaya). Wypowiedzenie formuły przyjęcia schronienia w tzw. trzech klejnotach (Buddzie, dharmie i buddyjskiej wspólnocie), która rozpoczyna rozmaite obrzędy, jest aktem wstąpienia do kręgu istot chronionych przez Buddę albo aktem potwierdzenia przynależności do tego kręgu ${ }^{10}$. Praktykom o charakterze magicznym otwierało drogę przeświadczenie, że eliminacja zagrożeń oraz szerzej rozumiana pomyślność mogą być osiągane nie tylko dzięki cielesnej obecności Śakjamuniego, ale również za pośrednictwem obiektów i zachowań, które Buddę reprezentują i w pewien sposób uobecniają.

Buddyści wierzyli, że Budda jest stale obecny w miejscach, w których przebywał za życia lub w których znajdują się jego szczątki ${ }^{11}$. Zrozumiałe jest więc pielgrzymowanie do tych miejsc i dążenie do wykorzystania dobroczynnej mocy Przebudzonego za pomocą rytuałów. W ten schemat można wpisać zarówno wczesne formy kultu Śakjamuniego, jak również, później wprowadzone i

${ }^{9}$ Zwolennicy przywołanego poglądu twierdzą, że zgodnie z buddyjską doktryną przebieg ludzkiego życia jest efektem wcześniejszych działań danej osoby (decyduje o tym prawo karmana), zaś los może zostać pomyślnie skorygowany wyłącznie dzięki moralnemu zachowaniu i osobistym postępom na ścieżce duchowego rozwoju. W tej perspektywie praktyki o charakterze magicznym są ignorowane albo uznawane za zjawisko wtórne i wypaczające buddyzm. Zob. np. Lance S. Cousins, „Buddhism”, w: A New Handbook of Living Religions, red. John R. Hinnells (London: Penguin Books, 1997), 409410.

${ }^{10}$ Peter Skilling, „The Rakșā Literature in the Śrāvakayāna”, Journal of the Pali Text Society 1992, nr 16: 111-112.

${ }^{11} \mathrm{Na}$ temat przekonania buddystów o aktualnej obecności Buddy w pewnych miejscach, w których przebywał za życia, zob. Gregory Schopen, „Burial 'Ad Sanctos' and the Physical Presence of the Buddha in Early Indian Buddhism. A Study in the Archeology of Religions”, Religion 17, nr 3 (1987): 194-197. Co do obecności w szczątkach zob. tamże, 203-211. 
promowane przez mnichów, kulty stup oraz wizerunków Buddy. Powszechny zwyczaj umieszczania stupy w klasztornych kaplicach miał zapewnić stałą obecność Przebudzonego w monastycznej wspólnocie. Kulminacją tego podejścia było przedzielanie Budzie odrębnego pomieszczenia mieszkalnego w klasztorach i uznawanie Śakjamuniego za prawnego właściciela majątku monastycznej wspólnoty. Powstanie stup jako ogólnodostępnych centrów kultowych zapewniało powszechny dostęp do relikwii buddystom świeckim i wpłynęło na rozwój odpowiednich praktyk magicznych. Przyjmowano również, że dosłownie rozumiana bliskość Buddy wpływa korzystnie na los zmarłych (np. zapewnia im narodziny w niebiosach), co prowadziło do składania szczątków mnichów i osób świeckich w małych stupach w pobliżu głównej stupy z relikwiami ${ }^{12}$.

Prosta interpretacja działań magicznych w buddyzmie uwzględnia traktowanie ich jako aktywności, którą można przeciwstawić moralnie kwalifikowanym czynom wyznaczającym przebieg życia (czyny te wywołują określone skutki na mocy karmicznych prawidłowości uznawanych za powszechne, stałe i naturalne). Wydaje się jednak, że magiczny paradygmat wchodził w głęboką interakcję ze sposobem rozumienia karmicznych mechanizmów. Pewne działania opisywane były w kategoriach moralnych (np. akty donacji na rzecz centrów kultowych traktowano jako świadectwo hojności) i w kategoriach prawidłowości karmicznych (generować mają wyjątkową zasługę), ale zarazem ich szczególna skuteczność wydaje się być zależna od działania cudownej mocy Buddy. Jeszcze przed powstaniem mahajany uznanie zyskał pogląd, zgodnie z którym zasługa zdobyta dzięki pewnym działaniom może zostać przeniesiona na inne osoby (w tym osoby zmarłe $)^{13}$. De facto doktryna ta sankcjonowała miejscowe zawieszanie fundamentalnej zasady adekwatnej odpłaty za własne czyny, co w kontekście buddyjskiej wizji rzeczywistości wymaga ingerencji czynnika supranaturalnego. Rzecz wymaga systematycznych badań, niemniej piszący te słowa przyjmuje, że odnoszenie przez buddystów pojęć z zakresu etyki i doktryny karmana do pewnych praktyk

${ }^{12}$ Gregory Schopen, „The Buddha as an Owner of Property and Permanent Resident in Medieval Indian Monasteries", Journal of Indian Philosophy 18, nr 3 (1990): 181-217; Schopen, Burial 'Ad Sanctos', 197-199, 200-201, 211-212; Robert DeCaroli, Haunting the Buddha: Indian Popular Religions and the Formation of Buddhism (Oxford: Oxford University Press, 2004), 98-100.

${ }^{13}$ Gregory Schopen, „Two Problems in the History of Indian Buddhism: The Layman/Monk Distinction and the Doctrines of the Transference of Merit", w: Bones, Stones, and Buddhist Monks: Collected Papers on the Archaeology, Epigraphy, and Texts of Monastic Buddhism in India, red. Gregory Schopen (Honolulu: University of Hawai'i Press, 1997), 34-43. 
religijnych nie wyklucza przyznania im statusu działań magicznych w wyżej określonym sensie.

Spektrum buddyjskich praktyk magicznych uległo znacznemu wzbogaceniu wskutek rozwoju, jakiemu podlegała rozprzestrzeniająca się religia. Magia w śrawakajanie obejmuje obrzędy związane z popularnymi formami kultu buddyjskich świętych, tj. siedmiu buddów, pratjekabuddów oraz arhatów. Buddyjska magia uległa wpływowi przed- lub niebuddyjskich form religijności, wchłaniając kulty rozmaitych istot nadprzyrodzonych (m.in. jakszów, nagów, tzw. Czterech Wielkich Królów, nikczemnych czy sfrustrowanych duchów osób zmarłych). Rola postawy inkluzywnej w śrawakajanie była przez badaczy buddyzmu często pomniejszana, a reprezentujące ją zjawiska traktowano jako peryferyjne czy niereprezentatywne dla środowisk monastycznych. Nowe badania wykazały, że wierzenia związane z tradycyjnie czczonymi i często budzącymi lęk mitologicznymi postaciami były ważną i integralną częścią już wczesnego buddyzmu. Buddyjscy mnisi aspirowali do władzy nad takimi istotami, dzięki czemu łatwiej było uzasadnić regułę, zgodnie z którą świeccy wyznawcy mają obowiązek zapewnić środki utrzymania monastycznej wspólnocie. Wierzono, że niektóre z owych istot przyjęły buddyjską naukę i stały się opiekunami buddystów. Otworzyło to drogę do powszechnej obecności wizerunków mitologicznych postaci obcej proweniencji w buddyjskich centrach kultowych oraz legitymizowało obrzędy służące zjednywaniu sobie takich istot. Nie kwestionowano ich wpływu na bezpieczeństwo i pomyślność wyznawców buddyzmu, chociaż potępiano ofiary krwawe i dary z alkoholu, a także przyjmowano, że życzliwość rozpatrywanych istot zyskać dzięki moralnemu postępowaniu i aktom donacji na rzecz klasztorów. Rozpatrywany proces inkluzji obcych form kultu znacząco przyczynił się do akceptacji buddyzmu (religii o elitarnej soteriologii) przez szersze kręgi społeczeństwa ${ }^{14}$.

W magii śrawakajany ważna rola przypada recytacji tekstów ochronnych lub zapewniających doczesną pomyślność (dalej będę mówić krótko o tekstach ochronnych). Zdaniem Petera Skillinga, jest to zjawisko, które sięga okresu sprzed wielkiej schizmy i ma charakter ogólno-buddyjski ${ }^{15}$. Możliwe, że do kanonów

${ }^{14}$ DeCaroli, Haunting the Buddha, szczególnie 38-62, 68-86.

${ }^{15}$ Skilling, „The Rakṣā Literature”, 168. Jednym z najstarszych świadectw rozpatrywanego zjawiska jest A̦tānățika-sūtra, której wersje wchodzą w skład kanonów therawadinów, sarwastiwadinów i mulasarwastiwadinów. Użycie magicznych formuł służyć ma w pierwszym rzędzie, według tego tekstu, zapewnieniu bezpieczeństwa medytującym mnichom. Zob. Ingo Strauch, „The Evolution of the 
mahasanghików i szkół wywodzących się od nich należał odrębny kosz zawierający teksty, których recytacji przypisywano funkcję ochronną (Vidyādhara-pițaka, Mantra-pitaka). Tego rodzaju teksty funkcjonowały również w innych szkołach śrawakajany. Skilling nazwał je „literaturą rakszy (sanskr. rakṣa - 'ochrona')”. Literatura ta obejmuje pewne sutry kanoniczne, sutry apokryficzne, pieśni (gathā) oraz inne teksty. Zdaniem Skillinga, apogeum rozwoju tekstów ochronnych i związanych z nimi obrzędów przypada na okres od II w. przed Chr. do III w. po Chr. Tekstami ochronnymi posługiwali się na co dzień zarówno mnisi (pragnący zapewnić sobie bezpieczeństwo), jak i buddyści świeccy. Wypowiadanie takich tekstów stało się głównym składnikiem rytuałów, w których wykorzystywano wodę i nitki (zapewne ogólno-indyjskie akcesoria obrzędów ochronnych). Recytacja tekstów ochronnych była również integralnym elementem kultu stup. Spisane składano w stupach lub posługiwano się nimi jako amuletami. Również kopiowaniu tych tekstów przypisywano dobroczynną moc. W therawadzie recytacja tekstów rakszy (określanych mianem paritta) zajmuje ważne miejsce do dnia dzisiejszego ${ }^{16}$.

W śrawakajanie ważną rolę odgrywa pogląd, zgodnie z którym skuteczność tekstów ochronnych opiera się na dobroczynnej mocy aktu wypowiedzenia prawdy (satya-vāk, satya-adhișthāna, satya-kriyā). Przekonanie to nawiązuje do wedyjskiej koncepcji uzyskania władzy nad światem w rezultacie pełnego dostrojenia się do kosmicznego porządku ( $r t a)$, ale w wersji buddyjskiej nacisk został położony na nieodpartą moc poznawczej i moralnej doskonałości, która została osiągnięta przez Buddę. Moc ta może zostać uobecniona i wykorzystana dzięki przywołaniu słów Śakjamuniego. W duchowych defektach osoby recytującej widziano czynnik, który może utrudniać apotropaiczne oddziaływanie tekstu. W wielu przypadkach dobroczynne rezultaty recytacji tekstów uznawano jednak za efekty aktywizacji mocy, która jest przynależna innym istotom lub obiektom.

\footnotetext{
Buddhist rakṣ̄āGenre in the Light of New Evidence from Gandhāra: The Manasvi-nāgarāja-sūtra from the Bajaur Collection of Kharoșțī Manuscripts”, Bulletin of SOAS 77, nr 1 (2014): 64-65.

${ }^{16}$ Skilling, „The Rakṣa $\bar{a}$ Literature”, 113-144, 160-169. Teksty reprezentujące literaturę rakszy wpłynęły na treść sutr Wielkiego Wozu. Mantry z niej pochodzące (podobnie jak rytualne zachowania wykorzystujące wodę lub nitki) były wykorzystywane przez wyznawców mahajany i wadźrajany w kontekstach rytualnych charakterystycznych dla tych tradycji (tamże, 160, 167). Charakterystykę cejlońskich rytuałów związanych z recytacją tekstów ochronnych znaleźć można w: Lily de Silva, „The Paritta Ceremony of Sri Lanka: Its Antiquity and Symbolism", w: Buddhist Thought and Ritual, red. David J. Kalupahana (New York: Paragon House, 1991), 139-150.
} 
Literatura rakszy pozostawała w bliskim związku z popularnymi formami kultu buddyjskich świętych, ulegając również wpływowi przed- lub niebuddyjskich form religijności. Skutkiem tego ostatniego zjawiska jest obecność magicznych formuł obcego pochodzenia oraz wykazów zapożyczonych imion istot nadprzyrodzonych ${ }^{17}$.

W literaturze rakszy bardzo ważną rolę odgrywają mantry, czyli zaklęcia, których funkcją jest oddziaływanie na rzeczywistość niezależnie od ich ewentualnej funkcji komunikacyjnej. Mantry często zawierają wyrażenia pozbawione znaczenia lub niezrozumiałe (przejęte $\mathrm{z}$ niebuddyjskich zaklęć). Mantry są często zbiorami syntaktycznie nieuporządkowanych słów. Mogą zawierać magicznie efektywne jakoby imiona istot nadprzyrodzonych, nazwy trucizn lub środków leczniczych (zgodnie z przekonaniem, że nazwy umożliwiają kontrolowanie zjawisk przez nie oznaczanych). Skilling sądzi, że w buddyzmie mantrami posługiwano się od początku ery chrześcijańskiej. Mantry dodawano do istniejących tekstów rakszy (włączając je w ich strukturę lub tworząc suplementy) albo tworzono teksty nowe zawierające mantry ${ }^{18}$. W tzw. maha-sutrach (mahā-sütra) sarwastiwadinów i mulasarwastiwadinów znalazły wyraz dwa wpływowe poglądy, które legitymizowały mantry obcego pochodzenia. Zgodnie z pierwszym, ostatecznym źródłem mantr jest Budda, zaś według drugiego Śakjamuni zaakceptował użycie ochronnych zaklęć, których źródłem są inne istoty nadprzyrodzone ${ }^{19}$. Często wyrażane jest przekonanie, że mantry i inne teksty ochronne są, w ramach przypisywanych im zastosowań, niezawodne. Zwolenników znajdował jednak również pogląd przeciwny (być może reprezentujących starsze podejście), zgodnie z którym zaklęcia nie chronią przed zdarzeniami stanowiącymi karmiczne owoce wcześniejszych czynów. Taki pogląd nie musi odzwierciedlać stanowiska zdecydowanie krytycznego go względem magicznego zastosowania tekstów czy mantr. Można w nim widzieć próbę wyjaśnienia fiaska konkretnych działań magicznych bez intencji generalnego kwestionowania wartości rozpatrywanej postaci magii ${ }^{20}$.

${ }^{17}$ Skilling, „The Rakșā Literature”, 144-149, 154-156, 159; Pedro Manuel Castro Sánchez, The Indian Buddhist Dhārañī: An Introduction to Its History, Meanings and Functions (PhD dissertation, University of Sunderland, 2011), 18, 22.

${ }^{18}$ Przykładem pierwszej klasy tekstów mogą być sanskryckie warianty sutry Āṭānātika, zaś wczesnym przykładem drugiej Manasvi-nāgarāja-sutra z I-II w. po Chr. Por. Strauch, „The Evolution of the Buddhist rakṣā Genre", 65, 67-75.

${ }^{19}$ Castro Sánchez, The Indian Buddhist Dhāraṇī, 23-24.

${ }^{20}$ Skilling, ,The Rakṣā Literature”, 148-149. 


\section{Ogólna charakterystyka magii w mahajanie}

Chociaż Wielki Wóz rodził się jako ruch niechętny kultom stup i wizerunków (mnichom w konserwatywnym duchu zalecano studiowanie ksiąg, medytację i nauczanie), to magia w tym odłamie buddyzmu szybko zyskała na znaczeniu ${ }^{21}$. Powszechne uznanie zdobył pogląd, zgodnie z którym Śakjamuni i inni buddowie przebywają w oddalonych regionach kosmosu, bez trudu ingerując w życie wyznawców buddyzmu. Przyjmowano również, że niesieniu wszechstronnej pomocy buddystom całkowicie poświęcają się bodhisattwowie (chociaż początkowo widziano w nich zwierzchników istot nadprzyrodzonych obcego pochodzenia, to $\mathrm{z}$ czasem ich postaci zlewały się $\mathrm{w}$ jedno $\mathrm{z}$ postaciami jakszów). ${ }^{22}$ Przekonanie o względnie łatwej dostępności czynników nadprzyrodzonych sprzyjało rozwojowi magicznych praktyk. Funkcję magiczną pełniły m.in. przejęte ze śrawakajany kulty stup i wizerunków ${ }^{23}$. Otaczane czcią były również sutry mahajany, co stanowiło kulminację tendencji do identyfikacji kultywowania buddyjskiej nauki z aktywną obecnością Buddy. Przyjmowano, że teksty te nie tylko przekazują naukę buddów, ale są również nośnikiem dobroczynnej mocy i uświęcają miejsce, w którym się znajdują ${ }^{24}$. W mahajanie chętnie posługiwano się zaklęciami (zawiera je wiele sutr mahajany ${ }^{25}$. Często przyjmowano, że ich zdolność magicznego przekształcania rzeczywistości oparta jest na partycypacji w cudownej mocy buddów

${ }^{21} \mathrm{Na}$ temat postawy krytycznej względem kultów stup i wizerunków we wczesnej mahajanie zob. Gregory Schopen, „On Sending the Monks to Their Books. Cult and Conservatism in Early Mahāyāna Buddhism”, w: Figments and Fragments of Mahāyāna Buddhism in India. More Collected Papers, red. Gregory Schopen (Honolulu: University of Hawai'i Press, 2005): 108-153; Gregory Schopen, „The Bones of a Buddha and the Business of a Monk: Conservative Monastic Values in an Early Mahāyāna Polemical Tract”, w: Figments and Fragments, red. Gregory Schopen, 63-107.

${ }^{22}$ DeCaroli, Haunting the Buddha, 174-182.

${ }^{23}$ Por. np. Paul Williams, Anthony J. Tribe, Buddhist Thought. A Complete Introduction to The Indian Tradition (London-New York: Routledge, 2000), 108-111.

${ }^{24}$ Zdaniem Schopena, to właśnie ów „kult ksiąg” (przeciwstawiany kultom stup i wizerunków) jest jednym z najważniejszych elementów oryginalnych wczesnej mahajany (Gregory Schopen, „Revisiting the Phrase sa prthivipradeśaś caityabhūto bhavet and the Mahāyāna Cult of the Book”, w: Figments and Fragments, red. Gregory Schopen, 25-62).

${ }^{25}$ Również w mahajanie zwolenników znajdował pogląd, zgodnie z którym zaklęcia nie chronią przed zdarzeniami stanowiącymi karmiczne owoce czynów. Pogląd ten był jednak często zdecydowanie odrzucany. Zob. Skilling, „The Rakṣā Literature”, 148-149; Ronald M. Davidson, „Studies in Dhāraṇī Literature I: Revisiting the Meaning of the Term Dhäraṇı̄", Journal of Indian Philosophy37, nr 2 (2009): 133-134. 
czy boddhisatwów, z zasady zorientowanej na pomoc cierpiącym istot. Obszerne sutry były kondensowane do postaci krótkich mantr jako ich magicznie efektywnych kwintesencji ${ }^{26}$. Świadectwem kulminacji zainteresowania magią w mahajanie wydają się być tzw. dharani-sutry, których autorzy śmiało czerpali z instrumentarium magii niebuddyjskiej, dokonali inkluzji magii złoczynnej i bez zastrzeżeń przypisywali magicznemu instrumentarium funkcję soteriologiczną.

W mahajanie akceptacja poglądu, zgodnie z którym instrumenty stosowane w magii mogą pełnić funkcję soteriologiczną, miała jednak znacznie szerszy zasięg. Popularnym celem religijnym stało się odrodzenie w cudownej krainie Sukhāvatī, osiągane jakoby m.in. dzięki rytuałom magicznym związanym z kultem określonego buddy czy bodhisattwy (niekoniecznie Amitabhy) ${ }^{27}$. O ile w śrawakajanie przyjmowano, że dzięki magicznej aktywności można zablokować pojawienie się karmicznych owoców wcześniejszych czynów, to w Wielkim Wozie zwolenników zyskał pogląd, zgodnie z którym analogiczne rytuały mogą oddziaływać na poziomie bardziej podstawowym. Pozwalają one jakoby trwale usuwać z umysłu tzw. splamienia (kleśa), czyli czynniki, które wymuszają podejmowanie działań karmicznie efektywnych (nieodwracalną eliminację wszystkich splamień utożsamiano ze zbawczą transformacją umysłu). Względnie konserwatywne uzasadnienie zbawczej roli mantr zostało przedstawione w Bodhisattva-bhümi. Zgodnie z nim, zbawcze zastosowanie mantry opiera się na medytacji mającej owo zaklęcie za przedmiot, bowiem medytacja taka pozwala osiągnąć gnostyczny wgląd (tradycyjnie uznawany za przyczynę zaniku splamień). Mantry mogą być uznane za właściwe przedmioty medytacji generującej gnozę, gdyż są pozbawione funkcji poznawczej (ewentualnie taka ich funkcja jest nieistotna), która jakoby utrudnia dostrzeżenie tego, co rzeczywiste (w filozofii mahajany rzeczywistość jest przeciwstawiana semantycznym korelatom nazw rozumianym jako substancjalne obiekty ${ }^{28}$. Tego rodzaju reinterpretacje instrumentów magicznych zdają się świadczyć o powszechnym uznaniu, jakim magia cieszyła się wśród buddystów. Matthew Kapstein skłonny jest sądzić, że rytuały z wykorzystaniem mantr były

${ }^{26}$ Skilling, „The Rakṣā Literature”, 150-154, 160-161; Castro Sánchez, The Indian Buddhist Dhāraòī, 81-82.

${ }^{27}$ Gregory Schopen, „Sukhāvatī as a Generalized Religious Goal in Sanskrit Mahāyāna Sūtra Literature", w: Figments and Fragments, red. Gregory Schopen.

${ }^{28}$ Castro Sánchez, The Indian Buddhist Dhāraṇī, 61-62; Davidson, „Studies in Dhāraṇī Literature I”, 133-137; Skilling, „The Rakșā Literature”, 153. 
powszechnie wykorzystywane do celów magicznych i soteriologicznych przy akceptacji buddyjskich uczonych od III w. po $\mathrm{Chr}^{29}$.

Jako nazwa tekstów pełniących funkcję magiczną rozpowszechnił się w mahajanie sanskrycki termin dhāraṇī. Słowo to ma szereg związanych ze sobą znaczeń. Etymologicznie rzecz biorąc, oznacza to, co uchwycone, podtrzymywane, zachowywane, chronione, lub środki, dzięki którym czynności, takie jak uchwycenie itd., mogą się dokonać. W nawiązaniu do etymologii, słowo było odnoszone do sprawności i cnót umysłu ważnych w perspektywie soteriologicznej oraz do środków, które umożliwiają ich osiągniecie ${ }^{30}$. Słowu nadano także sens węższy, w którym oznaczało rozmaite zjawiska językowe użytecznie soteriologicznie. Włączenie zaklęć do denotacji słowa dhāraṇi było równoczesnym wprowadzeniem ich w krąg wyrafinowanej myśli soteriologicznej, prowokującym czy wzmacniającym skojarzenia, tyleż inspirujące, co pożądane z punktu widzenia legitymizacji stosowania magicznych formuł w procesie zbawczej transformacji umysłu ${ }^{31}$. Płaszczyzną powstawania takich asocjacji była dominująca w mahajanie koncepcja języka. Zgodnie z nią, realizacja soteriologicznego celu stanowi wielostopniową i wieloaspektową recepcję (interioryzację) tekstu, w którym została wyrażona buddyjska nauka. W takiej perspektywie religijnie istotnym cnotom i sprawnościom, oraz działaniom prowadzącym do ich uzyskania, można przypisać aspekt językowy. Językowi, rozpatrywanemu w aspekcie funkcji komunikacyjnej i funkcji formowania wzorca aktywności, przyznano tym samym rolę zbawczą. Tak rozumiana aktywność językowa nie pełni jednak funkcji zbawczej samodzielnie, bowiem ostatecznie musi zostać przekroczona i uzupełniona przez gnostyczny wgląd, który pozwala ujawnić się rzeczywistości oraz zrozumieć, że semantyczne kategorie są względem niej nieadekwatne. To właśnie ów wgląd stanowić ma fundament cudownej, transformacyjnej mocy zaklęć. Zaklęcie stanowi bowiem akustyczne i powszechnie dostępne ucieleśnienie gnozy ${ }^{32}$. Zważywszy na

${ }^{29}$ Matthew Kapstein, Reason's Traces: Identity and Interpretation in Indian and Tibetan Buddhist Thought (Boston: Wisdom Publications, 2001), 245.

${ }^{30}$ Castro Sánchez, The Indian Buddhist Dhāraṇī, 34-35.

${ }^{31}$ Davidson wykazał jednak, że (wbrew starszym badaczom mahajany) odniesienie słowa do zaklęć nie było posunięciem wtórnym (ani tym bardziej świadectwem degeneracji poglądów), które można przeciwstawiać początkowej praktyce łączenia terminu z pamięcią i formułami mnemotechnicznymi. Użycie słowa w odniesieniu do zaklęć należy do najstarszych i najważniejszych jego zastosowań. Zob. Davidson, „Studies in Dhāraṇī Literature I”, 106-107, 116-117.

${ }^{32}$ Por. Castro Sánchez, The Indian Buddhist Dhāraṇī, 38-43. 
związek gnostycznego wglądu ze stanem buddy, można uznać, że nie odbiegliśmy daleko od wczesnobuddyjskiego poglądu, zgodnie z którym to dzięki swym duchowym osiągnięciom Budda jest źródłem dobroczynnej i nadprzyrodzonej mocy wykorzystywanej w praktykach magicznych.

Słowo dhāraṇi było odnoszone do kilku klas językowych zjawisk uznawanych za soteriologicznie użyteczne. Były to zaklęcia, sutry mahajany (przekazujące przesłanie soteriologiczne), pewne zespoły sylab (poszczególnym sylabom przyporządkowano określone buddyjskie prawdy czy kategorie doktrynalne) wykorzystywane do celów mnemotechnicznych lub medytacyjnych (podobnie jak tzw. matriki [matrka] w śrawkajanie), a także pojedyncze sylaby (szczególnie sylaba a interpretowana jako partykuła przecząca) rozpatrywane w funkcji przedmiotów medytacji generującej gnostyczny wgląd. Zjawiskom każdej z tych klas można przypisać odmienną rolę religijną, ale poszczególne funkcje ekstrapolowano na zjawiska należące do innych klas. W rezultacie całym sutrom czy rozpatrywanym zespołom sylab przypisywano funkcję magiczną, zaś zaklęcia traktowano jako kwintesencję buddyjskiej nauki czy obiekt medytacji prowadzącej do gnostycznego wglądu. Magiczne podejście do języka mieszało się z traktowaniem go jako środka przekazu informacji i jako instrumentu, który pozwala przekroczyć myślenie kategorialne $e^{33}$.

\section{Magia w dharani-sutrach}

W perspektywie badań nad buddyjską magią szczególnie ważna jest odrębna klasa tekstów, których autorzy kluczową rolę w praktyce religijnej przyznawali recytacji zaklęć (dhāraṇi, mantra, vidyā). Te powstające między III a VIII w. po Chr. teksty są nazywane „dharani-sutrami” (dhāraṇi-sūtra), chociaż ich oryginalne

${ }^{33}$ Tamże, $75^{-77}, 81^{-} 83$. Nieco inaczej widzi to R. Davidson, którego zdaniem różne sposoby użycia słowa dhāraṇī w tekstach mahajany można sprowadzić do wspólnego mianownika. Polegałby on na odwołaniu się do semantycznej kategorii kodu czy kodowania. Znaczenie terminu byłoby doprecyzowywane kontekstowo, ale słowo zawsze wskazywałoby na językowy charakter desygnatu, jego funkcję polegającą na rozpowszechnianiu buddyjskiego przesłania (rozumianego jako sprawozdanie dotyczące treści zbawczego doświadczenia), integralność buddyjskiej nauki, fundamentalną rolę pamięci niezbędnej do dekodowania informacji przekazywanych za pomocą dźwięków lub liter, adekwatność desygnatu względem rzeczywistości, jego funkcję soteriologiczną oraz rytualną skuteczność. Zob. Davidson, „Studies in Dhārạī Literature I”, szczególnie 117-118, 120, 122-133, 138-142. 
tytuły nie zawsze zawierały słowo sūtra. Możliwe, że to chińscy translatorzy zaczęli konsekwentnie stosować ową nazwę, włączając zwrot Tuoluonijing (dhāraṇi-sūtra) do tłumaczeń tych tytułów indyjskich tekstów, które zawierały słowo dhāranī. Rozpatrywane teksty zwykle rozpoczynają się od narracji, która nadaje im status nauczania Buddy, a w takiej sytuacji tradycyjnie posługiwano się słowem sūtra. Dharani-sutry znacząco różnią się objętością. Zdecydowana większość z nich zawiera określone zaklęcia. Starsze teksty zawierają również wyjaśnienie pochodzenia przedstawionych zaklęć lub wykaz korzyści płynących z ich użycia. Nowsze uzupełniono o omówienie rytuałów towarzyszących recytacji. W rozbudowanych dharani-sutrach, które opisują skomplikowane rytuały tego rodzaju, podane są liczne zaklęcia odpowiednie dla poszczególnych faz obrzędu. Takie teksty mogą uwzględniać wykonanie kultowego wizerunku, przygotowanie mandali, konsekrację uczestników obrzędu, inicjację rytualnych specjalistów, przebieg wizualizacji itp. Teksty poświęcone zaklęciom łączono w zbiory. $Z$ dharani-sutrami związana jest obszerna literatura pomocnicza obejmująca rytualne instrukcje (vidhi) opisujące sposób posługiwania się zaklęciami ${ }^{34}$.

W dharani-sutrach ujawnienie zaklęć (na ziemi, w dziedzinie niebiańskiej albo mitycznym miejscu, takim jak stolica jakszów czy siedziba królów nagów) przypisywane jest jakiemuś buddzie (zazwyczaj), bodhisattwie albo innej istocie nadprzyrodzonej. Dharani ogłoszone przez buddę, wyemanowane z jego ciała albo wypowiedziane przez istotę upoważnioną stanowią słowa buddy (buddhavacana). W obrębie dharani można wyróżnić pozdrowienie tzw. trzech klejnotów, buddy, bodhisattwy lub wzywanego bóstwa (czasem również prośby) oraz zaklęcie właściwe. Na początku i końcu właściwego zaklęcia zwykle znajdują się sylaby czy słowa uznawane za mantry już w tradycji wedyjskiej. Zazwyczaj na początku znajduje się więc sylaba om (buddyści skojarzyli ją z trzema ciałami buddy), zaś na końcu zwroty, takie jak svāha $\bar{a}$, ùm phat, namah czy hüm phat svāhā. Właściwe zaklęcia zawierają zwroty w trybie rozkazującym, prośby, powtórzenia terminów, wykazy zjawisk należących do pewnej klasy lub zestawienia fonetycznie

${ }^{34}$ Koichi Shinohara, Spells, Images, and Mandalas. Tracing the Evolution of Esoteric Buddhist Rituals (New York: Columbia University Press, 2014), 91-92, 124; Gergely Hidas, „Dhāraṇī Sūtras”, w: Brill's Encyclopedia of Buddhism, t. 1, Literature and Languages, red. Jonathan Silk, Oskar von Hinüber, Vincent Eltschinger (Brill: Leiden, 2015), 131-132, 133-134; Jacob P. Dalton, „How Dhāraṇīs WERE Proto-Tantric. Liturgies, Ritual Manuals, and the Origins of the Tantras", w: Tantric Traditions in Transmission and Translation, red. David B. Gray, Ryan Richard Overbey (Oxford: Oxford University Press, 2016), 208-215. 
pokrewnych form językowych (takie zbiegi mają uaktywnić potencjał języka w sposób wykluczający ograniczenia), zwroty odnoszące się do kolejnych stopni intensyfikacji pewnego zjawiska oraz zwroty pozbawione sensu. Te ostatnie mogą pochodzić z języków drawidyjskich, stanowić imiona obcych istot nadprzyrodzonych, być rzekomymi słowami języka tych istot, nadawać zaklęciu charakter dźwiękonaśladowczy lub muzyczny walor (poszczególne przypadki należy interpretować odrębnie). Dharani często wymagają wstawienia we właściwym miejscu imienia beneficjenta lub sponsora obrzędu, w którym dane zaklęcie jest wykorzystywane ${ }^{35}$.

Podstawą form obrzędowości opisanych w dharani-sutrach jest przekonanie, że zaklęcia są nośnikiem mocy istot o nadludzkim statusie. Składają one w dharani-sutrach zapewnienie o skuteczności (samaya) właściwie zastosowanych zaklęć. Wsparcie czy błogosławieństwo (adhișthāna) jakiegoś buddy, bodhisattwy, bóstwa itp. (czy wielu takich istot równocześnie) stanowić ma rękojmię skuteczności dharani ${ }^{36}$. Do obrzędów związanych z recytacją dharani wprowadzono tzw. bóstwa wadźry (groźne bóstwa obcego pochodzenia), a ich ranga stopniowo wzrastała $^{37}$. Niektóre teksty dotyczące dharani były deifikowane. Zwykle (chyba jednak nie zawsze) proces ten zachodził już po powstaniu danego tekstu. W większości przypadków bóstwa uosabiające tekst były rodzaju żeńskiego ${ }^{38}$.

Dharani stały się podstawowym elementem różnorodnych i rozbudowanych rytuałów. Przyjmowano, że wiedza na temat tych rytuałów pochodzi z tego samego źródła, co same zaklęcia. Wierzono, że warunkiem skuteczności dharani jest odprawienie odpowiedniego obrzędu. Kluczowe w tym kontekście wydaje się dążenie do uobecnienia nadprzyrodzonej istoty, której moc ma zostać za pośrednictwem mantry wykorzystana (istota ta ma się pojawić i spełnić życzenie). Rosnąca złożoność obrzędów prowadziła do wyłonienia się grupy odpowiednich specjalistów. Rozbudowane rytuały towarzyszące recytacji dharani nierzadko trwały wiele dni. Obejmowały odpowiednie przygotowanie uczestników (ich oczyszczenie i zapewnienie im ochrony), wyznaczenie i zabezpieczenie przestrzeni rytualnej,

${ }^{35}$ Castro Sánchez, The Indian Buddhist Dhāraṇī, 70-75; Hidas, „Dhāraṇī Sūtras”, 129-130.

${ }^{36}$ Castro Sánchez, The Indian Buddhist Dhāraṇī,29-30.

${ }^{37}$ Shinohara, Spells, Images, and Mandalas, 70-71, 124-125, 142, 192-193. Bóstwa wadźry zachowały jednak ambiwalentny charakter, o czym świadczy choćby (znana z Sutry Wadźraśekhary) praktyka sprowadzania ich siłą. Wtórnie praktyka bywała stosowana w odniesieniu również do innych bóstw (tamże, 184, 189).

${ }^{38}$ Hidas, „Dhāranī Sūtras”, 134-135. 
zaproszenie, ugoszczenie ofiarami i odprawienie nadprzyrodzonych istot ${ }^{39}$. Stosowano mudry (odpowiednie gesty dłoni) i wizualizacje; wykorzystywano różańce (do liczenia wyrecytowanych zaklęć), rozmaite instrumenty liturgiczne i graficzne schematy. Do obrzędów włączano akty skruchy, ślubowania i życzenia pomyślności dla innych istot ${ }^{40}$. Rytuały towarzyszące recytacji dharani inkorporowały kult wizerunków istot nadprzyrodzonych (przede wszystkim buddów i bodhisattwów) oraz wchłonęły zachowania obrzędowe pochodzenia pozabuddyjskiego (m.in. konsekracje uczestników, inicjacje specjalistów oraz odrzucone w starszym buddyzmie ofiary ogniowe $)^{41}$. Materialne wizerunki były z czasem zastępowane przez akty wizualizacji Przyjęcie w mahajanie nowego modelu autorytatywności tekstów religijnych (odwołującego się do wizyjnych doświadczeń) szeroko otworzyło drzwi zapożyczeniom. Proces rozwoju i inkluzji prowadził, jak wskazuje Aaron M. Ullrey, do dostosowania obrzędów odprawianych przez buddystów do paradygmatu magii, który był charakterystyczny dla średniowiecznych Indii. Jego zwolennicy dążyli do uobecnienia nadprzyrodzonych istot i wykorzystania ich mocy za pomocą określonej palety środków, która obejmowała m.in. ofiary, mantry, mudry, wizerunki lub graficzne schematy ${ }^{42}$.

Często wymagano powtórzenia zaklęcia określoną ilość razy (liczby bywają zawrotne). Do liczenia czasem używano różańca. Zdarza się, że zalecana jest recytacja aż do wyczerpania recytującego. Dobroczynne skutki użycia dharani bywają uzależniane od liczby recytacji ${ }^{43}$. W niektórych przypadkach obrzędy towarzyszące recytacji zaklęć były połączone $\mathrm{z}$ kultem stup ${ }^{44}$. Zgodnie ze starszym

${ }^{39}$ Struktura złożonego i długiego obrzędu była określona przez serię mantr wykorzystywanych w poszczególnych fazach rytuału. Zaklęciom takim często przyporządkowywano określone mudry (specjalne gesty dłoni). Zdaniem Shinohary to właśnie połączenie zaklęć z mudrami zmieniło recytację we wszechstronnie angażującą aktywność (wymagano, by w czasie wykonywania mudry mieć określone myśli). Należy odróżniać zaklęcie (i związaną z nim mudrę), które generować ma pewien cudowny rezultat, od zaklęć (i odpowiednich mudr), których seria tworzy szkielet obrzędu służącego wywołaniu takiego rezultatu. Shinohara, Spells, Images, and Mandalas, 98-99, 100-101.

${ }^{40}$ Tamże, np. 59-63.

${ }^{41}$ Postać rytuałów opisanych w dharani-sutrach ewoluowała. Proces ten został zrekonstruowany przez Koichiego Shinoharę. Zwięzłe omówienie wyników tych badań znaleźć można w: tamże, XIVXVII.

${ }^{42}$ Aaron Michael Ullrey, „Grim Grimoires: Pragmatic Ritual in the Magic Tantras” (PhD dissertation, University of California, 2016), 616-625.

${ }^{43} \mathrm{~Np}$. Shinohara, Spells, Images, and Mandalas, 97, 113.

${ }^{44}$ Tamże, 103-104. 
sposobem traktowania sutr mahajany jako szczątków dharmicznego ciała buddy, zapisany tekst pewnych dharani-sutr czasem umieszczano w stupach. Zarówno temu aktowi, jak i późniejszym czynnościom kultowym związanym ze stupą, która zawiera dharani, przypisywano zdolność generowania karmicznej zasługi i spełniania życzeń. Zapisane dharani funkcjonowały również jako amulety. Główną formą stosowania zaklęć pozostała jednak zrytualizowana recytacja dharani ${ }^{45}$.

W dharani-sutrach często precyzyjnie wyliczano czynniki, przed którymi chroni określone zaklęcie (czasem wskazane są one w samym zaklęciu). Rola nazw tych czynników (podobnie jak imion istot, którym przypisywano dobroczynną moc) jest związana z przekonaniem o możliwości oddziaływania za pośrednictwem nazwy na jej desygnat. Obok sutr poświęconych osiągnięciu konkretnego celu, istnieją teksty uwzględniające szerokie spektrum intencji, zarówno doczesnych, jak i soteriologicznych (łącznie z osiągnięciem stanu buddy). Cele doraźne i soteriologiczne często tworzą nierozdzielną całość. Obrzędy związane z recytacją dharani bywały rozumiane nie jako jednorazowe przedsięwzięcie, ale jako czynność wielokrotnie i w długim okresie powtarzana, która konstatuje specyficzną postać systematycznej praktyki religijnej. Realizacji celów doczesnych służyły obrzędy chroniące przed rozmaitymi szkodliwymi czynnikami (śantika), wywołujące pomyślne zdarzenia czy intensyfikujące pożądane stany (pauștika), a także szkodzące innym istotom (abićâraka ${ }^{46}$. Te ostatnie pozostają w konflikcie z zasadami tradycyjnej etyki buddyjskiej. W obrębie celów doczesnych można wyróżnić cudowne i trwałe zdolności, jak umiejętność stawania się niewidzialnym czy latania. Domniemywać można, że wiara w możliwość ich zdobycia odgrywała ważną rolę w kreowaniu szczególnego społecznego statusu rytualnych specjalistów ${ }^{47}$.

Wymagano niezachwianej wiary w skuteczność zaklęć od tych, którzy się nimi posługują. Wyrażane jest przekonanie, że praktyka dharani jest skuteczna niezależnie od tego, czy jej adept postępuje moralnie. Niektóre teksty obiecują sukces nawet tym, których moralne winy są skrajnie ciężkie (zaklęcia pozwalają

${ }^{45}$ Castro Sánchez, The Indian Buddhist Dhāraṇī,59-60; Shinohara, Spells, Images, and Mandalas, 96-97.

${ }^{46}$ Shinohara, Spells, Images, and Mandalas, 118-119.

${ }^{47}$ Można to wiązać z koncepcją Ronalda Davidsona, zgodnie z którą transgresyjne tendencje charakterystyczne dla późniejszych tantr mają źródło w przeświadczeniu specjalistów od magicznych rytuałów o swym nadludzkim statusie (poprzez transgresję osiąganym lub potwierdzanym). Por. Ronald M. Davidson, Indian Esoteric Buddhism. A Social History of the Tantric Movement (New York: Columbia University Press, 2002), 171-176, 187-188, 194-201, 232-235. 
wiec uniknąć karmicznych owoców poważnych wcześniejszych czynów). Równolegle funkcjonował jednak pogląd, zgodnie z którym działanie mantry może zostać zablokowane przez karmiczne owocowanie złych czynów (pozwalało to wyjaśnić nieskuteczność odprawionych obrzędów). Pewne teksty w takich przypadkach po prostu zalecają zwiększenie liczby recytacji. Metoda wyzwolenia oferowana w dharani-sutrach, nawet jeśli względnie uciążliwa (np. wymagająca, by rytualną recytację mantry powtórzyć kilkaset tysięcy razy, lub obejmująca medytację), jest przedstawiana jako znacznie szybsza od metod tradycyjnych. Według Dharani-Sutry Uszniszawidźaji (Uṣnịșavijayā-dhāraṇi-sūtra) nawet zobaczenie zaklęcia Uszniszawidźaji zapisanego na fladze, stanie w cieniu takiej flagi i podobne zdarzenia wyzwalają od konieczności odradzania się w najniższych kosmicznych dziedzinach i zapewniają uzyskanie w przyszłości wyzwolenia z sansary ${ }^{48}$.

Teksty dotyczące dharani są bardzo zróżnicowane, jeśli chodzi o dobór zaklęć, przebieg rytuałów, ich cele i tożsamość adresatów, a także inne kwestie. Można jednak powiedzieć, że reprezentują tendencję do uznania recytacji zaklęć za najbardziej efektywny sposób operowania świętą mocą w celu przekształcania świata lub siebie, charakteryzują się praktycznym podejściem (niechęcią do doktrynalnych spekulacji) oraz dają świadectwo rytualnemu eklektyzmowi. Struktura rytuałów opisanych w dharani-sutrach podporządkowana jest uobecnieniu istot, których moc (skoncentrowana w zaklęciu) ma zostać w odpowiedni sposób wykorzystana.

Wadźrajna narodziła się w obrębie ruchu religijnego, który wytworzył dharani-sutry. Podstawą rytualnej aktywności opisywanej w tych tekstach jest recytacja zaklęć. Towarzyszyły jej jednak rozmaite czynności, których charakterystyczny dobór pozwala wyróżnić kilka wyłaniających się kolejno modeli rytualnych. Długotrwały i wielostopniowy rozwój tego rodzaju obrzędów doprowadził do powstania wzorców praktyki religijnej opisanych w takich tekstach, jak Mahāvairocanasūtra, Vajraśekhara-sūtra czy rytualne podręczniki Amoghawadźry. Wzorce te są uznawane za charakterystyczne dla wczesnej, ale już w pełni ukształtowanej wadźrajany. Wykorzystano w nich mudry, mandale, ofiary, inicjacje, wizualizacje i identyfikację z wizualizowanym bóstwem, czyli zachowania zalecane już w starszych dharani-sutrach. Nic dziwnego, że wiele dharani-sutr zostało ex post (tj. po

${ }^{48}$ Castro Sánchez, The Indian Buddhist Dhāraṇī, 26, 51, 54-64. 
ukształtowaniu się buddyzmu tantrycznego jako odrębnej formacji) zawłaszczonych i zaliczonych do klasy tantr, czyli kanonicznych tekstów wadźrajany. Wiele wczesnych tantr to zbiory instrukcji rytualnych, które wyłoniły się w rezultacie rozwoju pomocniczych tekstów do dharani-sutr ${ }^{49}$.

\section{Zakończenie}

Pogląd, zgodnie z którym obrzędy magiczne są w obrębie buddyzmu ciałem obcym, jest rażąco błędny, jeśli rozpatrywać go w perspektywie historycznej. Rozwój buddyjskiej magii sięga początków tej religii, zaś powstanie wadźrajany nie było w tym zakresie żadnym przełomem. Do praktyk magicznych odwoływali się powszechnie świeccy wyznawcy i mnisi reprezentujący indyjską śrawakajanę i mahajanę. Za rytuały magiczne w wyżej zdefiniowanym sensie można uznać tak rozpowszechnione praktyki buddyjskie, jak recytacja tekstów ochronnych, oddawanie czci Śakjamuniemu w miejscach szczególnie ważnych w jego życiu, kult stup czy kult wizerunków buddów i bodhisattwów. Obrzędowym działaniom charakterystycznym dla praktyk magicznych przypisywano funkcję zbawczą, co stanowi świadectwo ich rangi. Dążenie do rytualnego wpływania na przebieg zdarzeń osiągnęło kulminację w nurcie mahajany, który stworzył teksty zwane „dharanisutrami”. Dają one wyraz fascynacji magią jako narzędziem przekształcania otoczenia i samego siebie. Stanowią również świadectwo śmiałego czerpania z obcych tradycji liturgicznych (zaadaptowano m.in. ofiarę ogniową). W wielu dharani-sutrach mamy do czynienia z przypisaniem rytuałom o proweniencji magicznej statusu głównego czynnika w procesie zbawczej transformacji umysłu. Wadźrajana stanowi kontynuację podejścia znanego z dharani-sutr, chociaż, jako zjawisko dynamiczne, w przedstawionej charakterystyce się nie zamyka.

Jednostronne zainteresowania badaczy zachodnich w przeszłości oraz wpływ kultury Zachodu na elity buddyjskie w krajach azjatyckich w XIX w. leżą u podstaw przekonania, że buddyzm sprowadza się do rozwijania cnót moralnych, umiejętności medytacyjnych oraz mądrości. Wskazane podejście polegało na racjonalizowaniu tradycji buddyjskiej, co prowadziło do pomniejszania roli magii. Taki właśnie zracjonalizowany buddyzm był propagowany na Zachodzie jako

${ }^{49}$ Tamże, 28-32, 53; Kapstein, Reason's Traces, 236-245; Dalton, „How Dhāraṇīs WERE ProtoTantric", 216. 
oferta dostosowana do potrzeb lokalnych odbiorców ${ }^{50}$. Ci, którzy twierdzą, że magia jest obca duchowi buddyzmu zwykle przekraczają opisową perspektywę historyczną, mówiąc de facto o tym, czym buddyzm być powinien. Zajmują punkt widzenia zwolennika określonej postaci buddyzmu. Broniąc tezy o zasadniczej obcości buddyzmu i magii, można powoływać się na określoną naukową rekonstrukcję nauczania Śakjamunego. Zważywszy jednak na to, że istniejące źródła zostały spisane późno i są treściowo niejednorodne, wartość takiej argumentacji musi pozostać problematyczna.

\section{Bibliografia}

Baumann, Martin. „Global Buddhism: Developmental Periods, Regional Histories, and a New Analytical Perspective". Journal of Global Buddhism 2001, nr 2: 1-43.

Castro Sánchez, Pedro Manuel. The Indian Buddhist Dhāraṇi: An Introduction to Its History, Meanings and Functions. PhD dissertation. University of Sunderland, 2011.

Cousins, Lance S. „Buddhism”. W: A New Handbook of Living Religions, red. John R. Hinnells, 369-444. London: Penguin Books, 1997.

Dalton, Jacob P. „How Dhäranīs WERE Proto-Tantric. Liturgies, Ritual Manuals, and the Origins of the Tantras". W: Tantric Traditions in Transmission and Translation, red. David B. Gray, Ryan Richard Overbey, 199-229. Oxford: Oxford University Press, 2016.

Davidson, Ronald M. Indian Esoteric Buddhism. A Social History of the Tantric Movement. New York: Columbia University Press, 2002.

Davidson, Ronald M. „Studies in Dhāraṇi Literature I: Revisiting the Meaning of the Term Dhāranı̄", Journal of Indian Philosophy 37, nr 2 (2009): 97-147. DOI: 10.1007/s10781008-9054-8

DeCaroli, Robert. Haunting the Buddha: Indian Popular Religions and the Formation of Buddhism. Oxford: Oxford University Press, 2004.

de Silva, Lily. „The Paritta Ceremony of Sri Lanka: Its Antiquity and Symbolism”. W: Buddhist Thought and Ritual, red. David J. Kalupahana, 139-150. New York: Paragon House, 1991. Gethin, Rupert. The Foundations of Buddhism. Oxford: Oxford University Press, 1998.

Hanegraaff, Wouter J. Esotericism and the Academy: Rejected Knowledge in Western Culture. Cambridge: Cambridge University Press, 2012.

Hidas, Gergely. „Dhāraṇī Sūtras”. W: Brill's Encyclopedia of Buddhism. Vol. 1, Literature and Languages, red. Jonathan Silk, Oskar von Hinüber, Vincent Eltschinger, 29-137. Leiden: Brill, 2015.

${ }^{50}$ Por. np. Martin Baumann, „Global Buddhism: Developmental Periods, Regional Histories, and a New Analytical Perspective”, Journal of Global Buddhism 2001, nr 2: 7-11. 
Kapstein, Matthew. Reason's Traces: Identity and Interpretation in Indian and Tibetan Buddhist Thought. Boston: Wisdom Publications, 2001.

Middleton, John. „Magic: Theories of Magic”. W: Encyclopedia of Religion, red. Lindsay Jones, t. 8, 5562-5569. Detroit: Thomson Gale, 2005.

Samuel, Goeffrey. Civilized Shamans. Buddhism in Tibetan Societes. Washington-London: Smithsonian Institution Press, 1993.

Schopen, Gregory. „Burial 'Ad Sanctos' and the Physical Presence of the Buddha in Early Indian Buddhism. A Study in the Archeology of Religions", Religion 17, nr 3 (1987): 193-225. DOI: $10.1016 / 0048-721 \mathrm{X}(87) 90116-3$

Schopen, Gregory. „The Buddha as an Owner of Property and Permanent Resident in Medieval Indian Monasteries", Journal of Indian Philosophy 18, nr 3 (1980): 181-217. DOI: 10.1007/BF00190311

Schopen, Gregory. „Two Problems in the History of Indian Buddhism: The Layman/Monk Distinction and the Doctrines of the Transference of Merit". W: Bones, Stones, and Buddhist Monks: Collected Papers on the Archaeology, Epigraphy, and Texts of Monastic Buddhism in India, red. Gregory Schopen, 23-55. Honolulu: University of Hawai'i Press, 1997.

Schopen, Gregory. „On Sending the Monks to Their Books. Cult and Conservatism in Early Mahāyāna Buddhism”. W: Figments and Fragments of Mahāyāna Buddhism in India. More Collected Papers, red. Gregory Schopen, 108-153. Honolulu: University of Hawai'i Press, 2005.

Schopen, Gregory. „The Bones of a Buddha and the Business of a Monk: Conservative Monastic Values in an Early Mahāyāna Polemical Tract”. W: Figments and Fragments of Mahāyāna Buddhism in India. More Collected Papers, red. Gregory Schopen, 63-107. Honolulu: University of Hawai'i Press, 2005.

Schopen, Gregory. „Sukhāvatī as a Generalized Religious Goal in Sanskrit Mahāyāna Sūtra Literature". W: Figments and Fragments of Mahāyāna Buddhism in India. More Collected Papers, red. Gregory Schopen, 154-189. Honolulu: University of Hawai'i Press, 2005.

Schopen, Gregory. „Revisiting the Phrase sa prthivipradeśaś caityabhūto bhavet and the Mahāyāna Cult of the Book". W: Figments and Fragments of Mahāyāna Buddhism in India. More Collected Papers, red. Gregory Schopen, 25-62. Honolulu: University of Hawai'i Press, 2005.

Shinohara, Koichi. Spells, Images, and Mandalas. Tracing the Evolution of Esoteric Buddhist. New York: Columbia University Press, 2014.

Skilling, Peter. „The Rakṣā Literature in the Śrāvakayāna”, Journal of the Pali Text Society 1992, nr 16: 109-182.

Spiro, Melford E. Buddhism and Society: A Great Tradition and Its Burmese Vicissitudes. Berkeley-Los Angeles: University of California Press, 1982.

Strauch, Ingo. „The Evolution of the Buddhist raksā Genre in the Light of New Evidence from Gandhāra: The Manasvi-nāgarāja-sūtra from the Bajaur Collection of Kharoșthī Manuscripts", Bulletin of SOAS77, nr 1 (2014): 63-84. DOI: 10.1017/S0041977X14000044 
Ullrey, Aaron Michael. „Grim Grimoires: Pragmatic Ritual in the Magic Tantras”. PhD dissertation. University of California, 2016.

Williams, Paul, Anthony J. Tribe. Buddhist Thought. A Complete Introduction to The Indian Tradition. London-New York: Routledge, 2000.

\section{Summary}

\section{Buddhist magic before the emergence of Vajrayāna}

The view, that magical rituals represent a foreign element in Buddhism, is definitely wrong when examined from a historical perspective. The origins of Buddhist magic go back to the origins of that religion. Magical practices were common among lay people and monks in Indian Śrāvakayāna and Mahāyāna. Recitation of protective texts, venerating of Śākyamuni in places especially significant in his life, worship of stupas and images of Buddhas and Bodhisattvas are widespread Buddhist rituals. The ritual acts characteristic of magical practices have even been assigned a salvific function, which fact bears out their enormous importance. The tendency to influence the course of events by magical rituals culminated with the Mahāyāna movement known from the Dhāraṇi Sūtras papers. They are also a testimony of the bold use of alien liturgical traditions. In many Dhāraṇi Sūtras, magical rituals possessed the status of being the main factor in the saving transformation of the mind. Vajrayāna evolved from Dhāraṇi Sūtras.

Keywords: Buddhism, magic, dhāraṇī, Dhāraṇī Sūtras

\section{Zusammenfassung}

\section{Buddhistische Magie vor der Entstehung von Vajrayāna}

Die Ansicht, dass die magischen Rituale innerhalb des Buddhismus ein fremdes Element bilden, ist, in der historischen Perspektive betrachtet, grundsätzlich falsch. Die Entwicklung der buddhistischen Magie geht auf die Anfänge dieser Religion zurück. Auf die magischen Praktiken bezogen sich säkulare Anhänger und Mönche, die indische Śrāvakayāna und Mahāyāna repräsentierten. Als magische Rituale können weit verbreitete buddhistische Praktiken angesehen werden, wie die Rezitation von schützenden Texten, die Anbetung von Śākyamuni an Orten, die in seinem Leben wichtig waren, die Anbetung von Stupa, die Verehrung der Bilder von Buddhas und Bodhisattvas. Den rituellen Handlungen, die für magische Praktiken charakteristisch sind, wurde sogar eine Heilsfunktion zugeschrieben, was ihren Rang bezeugt. Das Streben 
nach ritueller Beeinflussung des Handlungsverlaufs fand seinen Höhepunkt in der Strömung Mahāyāna, die für die sog. Dhāraṇi-Sūtras-Texte bekannt ist. Sie sind Ausdruck der Begeisterung für die Magie als Werkzeug der Umwandlung von seiner Umwelt und von sich selbst. Sie sind auch ein Zeugnis für ein kühnes Schöpfen aus fremden liturgischen Traditionen. In vielen Dhāraṇī-Sūtras handelt es sich darum, dass den Ritualen mit magischem Ursprung der Status des Hauptfaktors im Prozess der erlösenden Transformation des Geistes zugeschrieben wird. Vajrayāna entwickelte sich auf der Grundlage eines Ansatzes, der aus Dhāraṇi-Sūtras bekannt ist.

Schlüsselworte: Buddhismus, Magie, Dhāraṇī, Dhāraṇī-Sūtras

Information about Author:

MAREK SZYMAŃSKI, habilitated doctor, Institute of Philosophy, Maria Curie-Skłodowska University, Poland; address for correspondence: Instytut Filozofii UMCS, Pl. M. Curie-Skłodowskiej 4, PL 20-031 Lublin; e-mail: marek.szymanski@poczta.umcs.lublin.pl

\section{(cc) EY-NC-ND}

